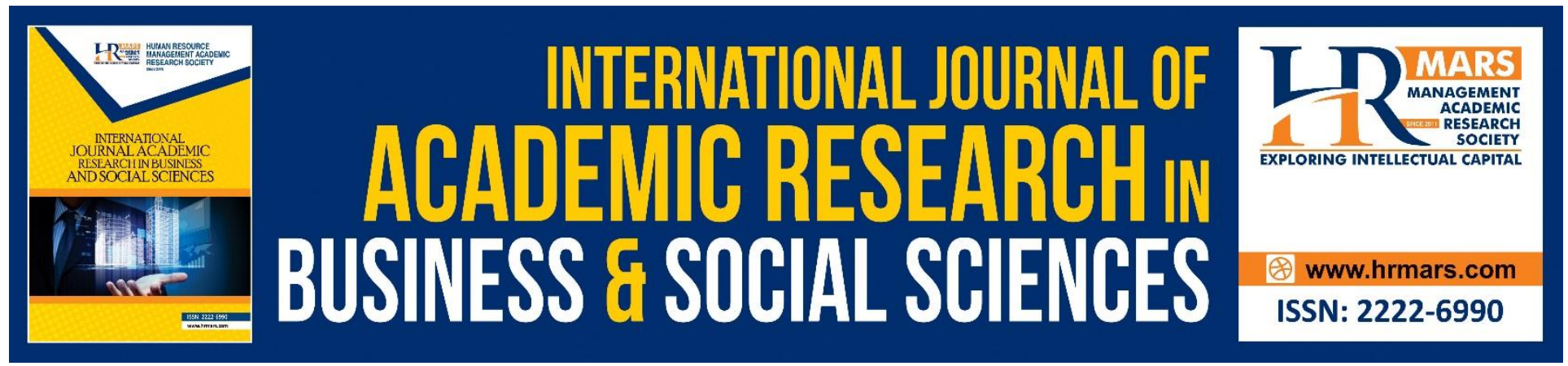

\title{
Emergency Contraceptive Pill Usage: How Community Pharmacists Can Communicate with Young Female Adults?
}

Chang You, Leiu, Zoharah, Omar, Siti Noormi, Alias, Nur Aira, Abd Rahim

To Link this Article: http://dx.doi.org/10.6007/IJARBSS/v10-i10/7697

DOI:10.6007/IJARBSS/v10-i10/7697

Received: 27 August 2020, Revised: 29 September 2020, Accepted: 19 October 2020

Published Online: 30 October 2020

In-Text Citation: (Leiu, Omar, Alias, \&_Abd Rahim, 2020)

To Cite this Article: Leiu, C. Y., Omar, Z., Alias, S. N., \&_Abd Rahim, N. A. (2020). Emergency Contraceptive Pill Usage: How Community Pharmacists Can Communicate with Young Female Adults. International Journal of Academic Research in Business and Social Sciences. 10(10), 925-938.

Copyright: (C) 2020 The Author(s)

Published by Human Resource Management Academic Research Society (www.hrmars.com)

This article is published under the Creative Commons Attribution (CC BY 4.0) license. Anyone may reproduce, distribute, translate and create derivative works of this article (for both commercial and non-commercial purposes), subject to full attribution to the original publication and authors. The full terms of this license may be seen at: http://creativecommons.org/licences/by/4.0/legalcode

Vol. 10, No. 10, 2020, Pg. 925 - 938

http://hrmars.com/index.php/pages/detail/IJARBSS

JOURNAL HOMEPAGE

Full Terms \& Conditions of access and use can be found at http://hrmars.com/index.php/pages/detail/publication-ethics 


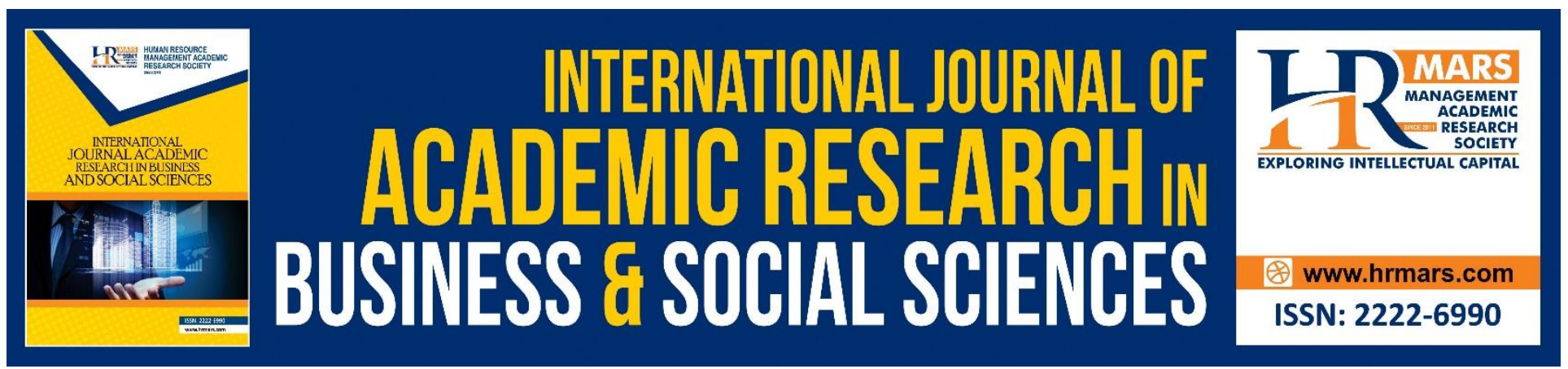

\title{
Emergency Contraceptive Pill Usage: How Community Pharmacists Can Communicate with Young Female Adults?
}

\author{
Chang You, Leiu, Zoharah, Omar, Siti Noormi, Alias, Nur Aira, Abd \\ Rahim
}

Department of Professional Development and Continuing Education, Faculty of Educational Studies Universiti Putra Malaysia

Email: moritzleiu@gmail.com, omarzoharah@gmail.com,noormiey@gmail.com, aira.abdrahim@gmail.com

\begin{abstract}
Emergency contraceptive pill (ECP) have been widely used by young women across the world to prevent unwanted pregnancy after an unprotected sexual intercourse. Community pharmacists are first line healthcare providers and play pivotal role in communicating correct use of emergency contraceptive pill. Given that the study of a communication guide particularly in the Malaysian setting is limited, this paper aims to explore the current pharmacy practice and effective communication channels in supply of emergency contraceptive pill to young female adults. Underpinning theory of Extended Parallel Process Model (EPPM) and Theory-informed media selection (TIMS) framework is discussed in the design of a health communication material. The outcome of study implies pharmacists to form an effective ECP communication channels to their respective pharmacy settings and to inform policy makers in the exploration of novel ECP information distribution channels in various healthcare settings in providing ECP information.
\end{abstract}

Keywords: Emergency Contraceptive Pill, Pharmacists, Health Communication, Communication Materials

\section{Introduction}

An unplanned pregnancy is a pregnancy that is reported to have been either unwanted or mistimed (Centers for Disease Control and Prevention, 2019). The worldwide rate of unintended pregnancy was 64 per 1,000 women aged 15-49 reported between year 2015 to 2019 (Bearak et al., 2020). In Malaysia, a nationwide cross-sectional study in public primary healthcare clinics showed $42.9 \%$ of the pregnancies were unplanned (Yusof, Samad, Omar, \& Ahmad, 2018). This finding is alarming since family planning services are offered free of charge by all public health facilities in Malaysia, yet contraception usage rates sare still reported low. Despite its ease of availability, the contraceptive 
prevalence rate in Malaysia for modern methods was $32 \%$, which is much lower in comparison to Singapore (55.1\%) and Thailand (77.5\%) (Najimudeen \& Sachchithanantham, 2014).

Multiple concurrent factors such as regularity of menstrual cycle and ovulation time make successful contraception a huge challenge (McKay \& Gilbert, 2014). In Malaysia, about 15\% married women reported lack of understanding in family planning (United Nations, 2015). While emergency contraceptive pill (ECP) have been proven safe and efficacious as means of emergency contraception, various misperceptions about its use remained, largely on the cancer-causing effects and side effects such as nausea, heavy bleeding, cramps and infertility (Westley \& Glasier, 2010). Combination of low understanding level and misperceptions on ECP discourages the use. This forms the cause of ECP not being considered as the form of contraception after an unprotected sexual event. What is more, in the country like Malaysia, where information on sexually related topics are often being discussed or shared scarcely. The process of communication to address the ECP understanding and misperception issues is constantly challenging.

Globally, the access of ECP has mostly been made conveniently from the community pharmacy without prescription. While this was expected to reduce delays in obtaining emergency contraception, however, a study showed that the number of self-reported unplanned pregnancies remained high (Michie \& Cameron, 2020). Only a small fraction of women who received advance provision of ECP by pharmacists used it correctly (Beyene, 2019). Limited studies explored the pharmacist's communication on the ECP topics. This study therefore carries the respective objectives:

- to explore the communication practices among community pharmacists in provision of ECP information; and

- to understand the importance of communication in health care.

The next section of this article will be discussing on the ECP and health communication models followed by methodology of the concept, roles of community pharmacists, issues with ECP supply and counselling, and communication in health care; before the conclusion with contributions of study, and implication and recommendations.

\section{Emergency Contraceptive Pill (ECP)}

ECP which better known as the 'morning after pill' is a hormonal pill purposed to reduce the risk of unwanted pregnancy after an unprotected sexual event (Trussell, Raymond \& Cleland, 2016). Most of the time, ECP is the top pick as post-coital contraceptive method attributable to the proven efficacy and safety profile of this pharmaceutical product (Thomin, Keller, Darai \& Chabbert, 2014). Similarly, ECP is widely available from community pharmacy in Malaysia. Although with its benefits and readily accessible, the responsible of use is not at the desire level. A Malaysia study mentioned the lacking in recommendation and provision of ECP information are the contributors of low ECP usage in the country (Alagrisamy \& Arokiasamy, 2019). The potential of maximising the adoption of ECP among women is prominent in view of the high rise of side effects from interventions such as abortion.

\section{Health Communication Models}

Instilling fear to evoke a change has been old-fashioned and proven unsuccessful in current society. In fact, encouragement and motivation are dominating the current trend in producing positive 
INTERNATIONAL JOURNAL OF ACADEMIC RESEARCH IN BUSINESS AND SOCIAL SCIENCES Vol. 10, No. 10, 2020, E-ISSN: 2222-6990 @ 2020 HRMARS

outcomes (Parvanta \& Bass, 2018; Zonouzy, Niknami, Ghofranipour, \& Montazeri, 2019). This reflected exceptionally well in the case of ECP use among young female adults especially the fear component such as the possibility of unintended pregnancy. A further distress from pharmacists while young female adults seeking for solution (the ECP) would discourage the communication process; hence, jeopardise the effectiveness of ECP use.

Typically, health communication should ideally be carried out with three strategies - engage, inform and persuade (Parvanta \& Bass, 2018). Engagement allows communicative interactions to occur and provides opportunities for information communication (Bernhardt, Mays, Eroğlu, \& Daniel, 2009; Higgins, Larson, \& Schnall, 2017). An effective communication could then lead to an opportunity in persuading and motivating for changes, which defines the health communication goal. Based on the educational approaches of Rothschild's behaviour management model, persuasion to trigger a change is dominant when the audience perceived to have more to gain than to lose and at the same time the information is simple, clear, and unambiguous (Parvanta \& Bass, 2018). This study is guided by the fundamentals of the health communication process and two health communication models, namely the Extended Parallel Process Model (EPPM) and Theory-informed media selection (TIMS) framework.

\section{Extended Parallel Process Model (EPPM)}

The Extended Parallel Process Model (EPPM) considered two aspects - threat (how dangerous is it to me?) and efficacy (what action can be taken to avoid the threat?) (Parvanta \& Bass, 2018). Threat denotes the belief of such threat is harmful while efficacy signifies knowledge and personal capability in avoiding the threat. Four audience segments are identified in the model (Figure 1) (Parvanta \& Bass, 2018): (1) 'danger control' audiences are young female adults who take action to eliminate the threat and for pharmacists to call upon their action; (2) 'fear control' audiences are young female adults who identified the threat but afraid to act to resolve the threat and for pharmacists to educate about solutions; (3) 'lesser amount of danger control' audiences are young female adults who know what to do but not motivated to do much and for pharmacists to educate about the threat; and (4) 'no response' audiences are young female adults who neither feel the risk nor knowing the solutions to threat and for pharmacists to educate about risk and solutions.

\begin{tabular}{|c|c|c|}
\hline & $\begin{array}{c}\text { High efficacy } \\
\text { Belief in effectiveness of solutions and } \\
\text { confidence to practice them }\end{array}$ & $\begin{array}{l}\text { Low efficacy } \\
\text { Doubts about effectiveness of solutions } \\
\text { and about one's ability to practice them }\end{array}$ \\
\hline $\begin{array}{c}\text { High threat } \\
\text { Belief that the threat } \\
\text { is harmful and that } \\
\text { one is at risk }\end{array}$ & $\begin{array}{l}\text { Danger control } \\
\text { People take protective action to avoid or } \\
\text { reduce the threat. } \\
\text { Strategy: Provide calls to action }\end{array}$ & $\begin{array}{l}\text { Fear control } \\
\text { People are too afraid to act, just try to } \\
\text { reduce their fear and feel better. } \\
\text { Strategy: Educate about solutions }\end{array}$ \\
\hline $\begin{array}{l}\text { Low threat } \\
\text { Belief that the threat } \\
\text { is trivial and that one } \\
\text { is not at risk }\end{array}$ & $\begin{array}{l}\text { Lesser amount of danger control } \\
\text { People know what to do but are not } \\
\text { really motivated to do much. } \\
\text { Strategy: Educate about risk }\end{array}$ & $\begin{array}{c}\text { No response } \\
\text { People don't feel at risk and don't know } \\
\text { what to do about it anyway. } \\
\text { Strategy: Educate about risk and about } \\
\text { solutions }\end{array}$ \\
\hline
\end{tabular}

Figure 1: Extended parallel process model (Parvanta \& Bass, 2018) 
INTERNATIONAL JOURNAL OF ACADEMIC RESEARCH IN BUSINESS AND SOCIAL SCIENCES Vol. 10, No. 10, 2020, E-ISSN: 2222-6990 @ 2020 HRMARS

In this study, this model particularly makes it useful in promoting ECP awareness when unplanned pregnancies persist as significant threats to women's reproductive health (Randrianasolo et al., 2008). Using the EPPM model, a communication material would be able to assist pharmacists during consultations by accommodating different audience segments with the respective strategies.

\section{Theory-informed media selection (TIMS) framework}

To guide reproductive health products selection, the Health Communication Capacity Collaborative developed the Theory-informed media selection (TIMS) framework. This framework incorporates combination of Media Richness Theory (MRT) and Uses and Gratifications Theory (UGT) (Figure 2) (Parvanta \& Bass, 2018).

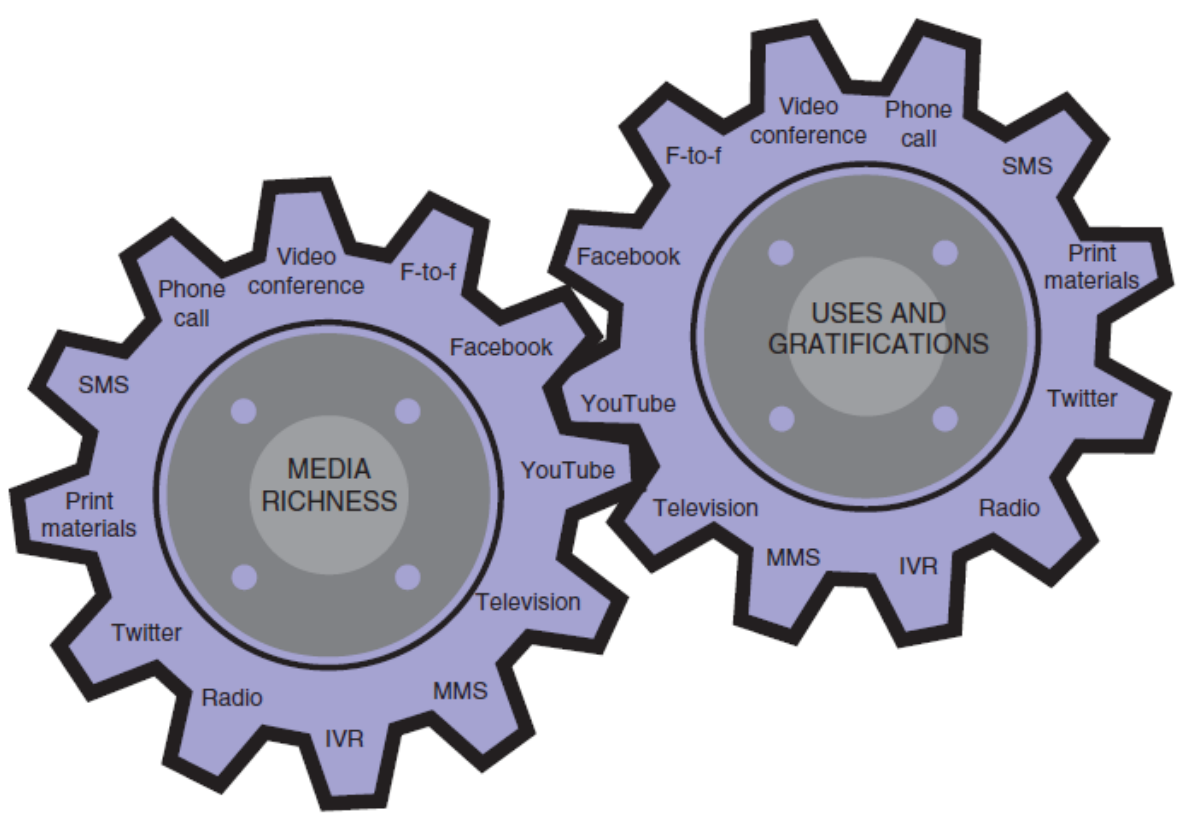

Figure 2. Theory-informed media selection (TIMS) framework (Parvanta \& Bass, 2018)

The MRT framework defined the media capacity in information transmission. It detailed use of richer communication media in addressing information with discussion (interactivity and feedback) and high level of customisation (language variety and real time information tailoring) to everyone with great affections (feeling and emotion) (Strekalova \& Krieger, 2017). Alongside, UGT framework studied the reasons of a preferred media preferred in achieving communication goals or those seeking for information (Korhan \& Ersoy, 2016). By selecting suitable media from MRT and UGT correspondingly, the overlapping media choice is the best option for such situation. In this study, face-to-face communication and print materials are the overlapping media to support pharmacist's communication process on ECP to young female adults in preventing unintended pregnancy. Faceto-face communication tends to be more effective in communicating rich and vague information because it allows discussion, instant feedback, high level of personalisation, and transmission of emotions. Printed materials reinforce verbal advice and result in improved understanding and acceptance of treatment recommendations. Written information should however be considered as a supplement to verbal counselling, rather than a replacement (Hersh, Salzman, \& Snyderman, 2015). 
INTERNATIONAL JOURNAL OF ACADEMIC RESEARCH IN BUSINESS AND SOCIAL SCIENCES Vol. 10, No. 10, 2020, E-ISSN: 2222-6990 @ 2020 HRMARS

\section{Methodology}

A literature search was conducted to understand the concept and use of communication materials in ECP communication in community pharmacy settings. The review was focused on three main areas, namely (1) healthcare communication, (2) pharmacists' roles in ECP communication, and (3) issues on use and communication of ECP in Malaysia. Studies set from year 2015 onwards were included. Key search terms using emergency contraception pill, pharmacist, communication, education and counselling, were used via Google Scholar. The full articles were screened through to identify and extract key supporting claims that were relevant to the write-up of this study.

\section{Roles of Community Pharmacists}

Effective contraceptive counselling and risk reduction behaviour was essential alongside effective use, promotion, and increased availability of emergency contraception to reduce unplanned pregnancy. An increase in familiarity with emergency contraception was also associated with increased likelihood of use, regardless of whether women had been offered emergency contraception in advance (Gonsalves \& Hindin, 2017). Community pharmacists are uniquely positioned to play pivotal role in encouraging communication with consumers to clarify potential misconceptions about using EC (Farris, Aquilino, Kimbel, Batra, \& Marshall, 2012; Gonsalves \& Hindin, 2017). The challenge to community pharmacists will be to provide the needed information in an inviting, non-judgemental manner so the customers take advantage of it (Ragland, Payakachat, \& Stafford, 2015). Generally, pharmacists are readily to provide ECP information. Though, the uneasiness among pharmacists in the delivery of sexual health information are common (Gonsalves \& Hindin, 2017). Likewise, counselling young female adults in presence of other customers or staff at the counter often leaves little room for privacy (Both \& Samuel, 2014; Gonsalves \& Hindin, 2017; Hattingh, Emmerton, Ng Cheong Tin, \& Green, 2016). EC use is only efficient if women could ask questions, and if they receive professional advice and benefit from privacy (Bitzer, Abalos, Apter, Martin, \& Black, 2016; Robbins \& Ott, 2017).

A common practice among most community pharmacists in ECP supply would involve handing the ECP to young adults readily and informing them to consume the pills twelve hours apart, instead of providing them with tailored, comprehensive advice (Batur, Kransdorf, \& Casey, 2016; Both \& Samuel, 2014; Todd \& Black, 2020). When providing counselling on the effective and safe ECP use, it is crucial for pharmacists to looking into consumers' comfort level in seeking additional information. The pharmacist-patient counselling session involves an intensive inquiry into the customers' medical history and thus risk scaring away uncomfortable customers (Hardavella et al., 2017). Customers who may not feel comfortable sexual-related health topics will be more reserved to ask pharmacists for further information (Peters et al., 2016). This resonates to challenges faced by pharmacists on ECP education, especially to young female adults, whereby they tend to hastily purchase ECP and are often too embarrassed to ask questions. Young adults frequently feel too shy to ask for more information from community pharmacists though they have many questions about ECP on the side effects and how to use them.

Concurrently, pharmacists did not give enough advice or information about future contraception and sexual health (Saxena, Mishra \& Nigam, 2016). Pharmacists are insufficiently skilled in communicating with adolescents regarding EC (Milosavljevic, Krajnovic, \& Bogavac-Stanojevic, 2016; Saxena et al., 
INTERNATIONAL JOURNAL OF ACADEMIC RESEARCH IN BUSINESS AND SOCIAL SCIENCES Vol. 10, No. 10, 2020, E-ISSN: 2222-6990 @ 2020 HRMARS

2016). Instead of proactively raising ECP topics for discussion, pharmacists were keener to respond only when prompted. It was also suggestive that encounter length between pharmacist and customers were dependent on patients proactively asking questions (Peters et al., 2016). This could potentially be addressed by introducing communication skills training to pharmacists (Kerr et al., 2017). Otherwise, the absence of clear ECP information may result in young female adults seeking information via informal channels such as from peers, brochures, and internet browsing (Both \& Samuel, 2014; Garrett, Widman, Francis, \& Noar, 2016). This raises concerns among service providers as peers and most websites are unreliable or able to provide accurate information on ECP (Garrett et al., 2016). As such, professional communication needs to be explored as an effective measure to overcome this issue.

\section{Issues with ECP Supply and Counselling}

In Malaysia, ECP have been made widely available and easily accessible from community pharmacies without the need of a prescription. There has been an increased use of ECP which was well accepted by all (Gajanan, 2015). This, however, did not reduce the incidences of unplanned pregnancy and abortion rates.

An observation into the standard practice in ECP supply would involve community pharmacists informing consumers to take the pills twelve hours apart (Both \& Samuel, 2014). With the convenience to ECP access, concerns exist in ECP misuse, especially among young female adults (Liambila, Obare, \& Keesbury, 2010; Yen, Parmar, Lin, \& Ammerman, 2015). On the other hand, indepth counselling session usually involves an intensive inquiry into the consumers' medical history and thus risk scaring away uncomfortable consumers (Hardavella et al., 2017; Liambila et al., 2010). Similar challenges were reported with reserved consumers who tend to hastily purchase ECP and often felt embarrassed asking questions about sexual-related health topics (Peters et al., 2016). Pharmacists, too, were reported to be insufficiently skilled in communicating with adolescents regarding EC and provided little advice or information about future contraception and sexual health (Milosavljevic et al., 2016; Saxena et al., 2016). Instead of proactively raising ECP topics for discussion, pharmacists were more keen to respond only when prompted (McAree \& Scott, 2004). It was also suggestive that encounter length between pharmacist and consumers were dependent on whether questions were proactively asked (Peters et al., 2016). The lack of ECP information may result in young female adults seeking information via other informal channels including their peers, brochures and internet browsing (Both \& Samuel, 2014; Garrett et al., 2016). This raised concerns among service providers as peers and most websites may relay unreliable or inaccurate on ECP (Garrett et al., 2016).

In a diverse ethnicity country like Malaysia, cultural background and traditional characteristics of different races could be additional challenge for the Malaysian community pharmacists in dealing with this sensitive health topic. Premarital unplanned pregnancy in Malaysia is evident with low awareness and knowledge of contraception and ECP availability (Wong, Atefi, Majid, \& Su, 2014; Zain, Low, \& Othman, 2015). This indicated the gap needs to be filled by community pharmacists as the primary and effective informant in reversing the situation. Another Malaysian study revealed that young adolescents expressed the need for more information about contraception (Fatimah, Razif, Hafizah, \& Aw, 2019). Hence, the need for protocols in EC provision that encompass counselling/referral guides and accessibility of materials (such as brochures, posters and package 
INTERNATIONAL JOURNAL OF ACADEMIC RESEARCH IN BUSINESS AND SOCIAL SCIENCES Vol. 10, No. 10, 2020, E-ISSN: 2222-6990 @ 2020 HRMARS

inserts) is evident (Liambila et al., 2010; Saxena et al., 2016). To the best knowledge of the authors, no known communication material is available in Malaysia to aid community pharmacists in providing a comprehensive and easy-to-understand educational session on ECP to young female adults. This subsequently gives the advantage to young female adults to better understand reproduction and contraception while indirectly encouraging pharmacist-patient communication.

\section{Communication in Health Care}

In healthcare settings, communication occurs in between medical providers or medical providers and patients. Regardless the targeted audience of communication, verbal, non-verbal, written, and visual are the four main types of communication practice in healthcare settings (Table 1) (Boyd \& Dare, 2014; Karanesheva, 2015).

Table 1. Types of communication in health care

\begin{tabular}{|c|c|}
\hline Verbal & $\begin{array}{l}\text { - Gain instant feedbacks compliment with emotions to enrich content and } \\
\text { gauge level of health literacy (Pagano, 2009) } \\
\text { - Instant rectification through interpretation and translation (Purnell, 2018) }\end{array}$ \\
\hline $\begin{array}{l}\text { Non- } \\
\text { verbal }\end{array}$ & $\begin{array}{l}\text { - Covers more than } 60 \% \text { of communication (Härgestam, Hultin, Brulin \& } \\
\text { Jacobsson, 2016) } \\
\text { - Supportive method to better understand reactions and thoughts (Park, } \\
\text { 2017) }\end{array}$ \\
\hline Written & $\begin{array}{l}\text { - Display of information in words (Purtilo, Haddad, \& Doherty, 2018) } \\
\text { - Commonly used when information transmission is complex } \\
\text { - } \quad \text { Can be kept as a record or reference for future use }\end{array}$ \\
\hline Visual & $\begin{array}{l}\text { - Use of pictures, illustrations, and charts in delivering complex information } \\
\text { (Mayer \& Villaire, 2007; Hersh et al., 2015) } \\
\text { - Relies on verbal or written communication for explanation } \\
\text { - Enables high retention in audience with different background and learning } \\
\text { style }\end{array}$ \\
\hline
\end{tabular}

Health communication have been recognised as important aspect in achieving good treatment outcomes and behavioural changes (Brooks, Manias, \& Bloomer, 2019; Lunsford et al., 2018). Health communication also incorporates the study and approaches to influence and enlighten the knowledge, attitudes and practices among individuals and the community on health aspects. From a patient's perspective, understanding information from healthcare providers and acting to carry out the given information are two distinct issues. It entails meaningful engagement on the options available in order to understand the patient and establish a dialogue between patient and medical providers on the evidence and the decisions in play (Epstein, Fiscella, Lesser, \& Stange, 2010; Higgins et al., 2017).

Community-based health communication interventions have been instrumental in the control of the Ebola crisis and past outbreaks (Santibañez, Siegel, O'Sullivan, Lacson, \& Jorstad, 2015; United Nations International Children's Emergency Fund, 2015a, 2015b); improved diabetic patients' selfcare and treatment satisfaction in United States (White et al., 2015); improved use of family planning 
INTERNATIONAL JOURNAL OF ACADEMIC RESEARCH IN BUSINESS AND SOCIAL SCIENCES Vol. 10, No. 10, 2020, E-ISSN: 2222-6990 @ 2020 HRMARS

methods in Ethiopian rural communities (Yitayal, Berhane, Worku, \& Kebede, 2014); strengthening health systems in both Japan and Zambia (Henning, Goto, Chi, \& Rudd, 2015); and reduced children's daytime asthma symptoms and urgent care visits in distressed communities in the United States (Gutierrez Kapheim, Ramsay, Schwindt, Hunt, \& Margellos-Anast, 2015). These successful stories have proven that health communication emphasised good health literacy, attitudes and practices and provides the people with enough information to make complex health decisions. In a larger community, health communication can move public agenda and advocate for policies and programs that promotes positive change in health (Karanesheva, 2015).

\section{Conclusions}

Good communication with young adults is important for healthcare providers. Young adults have unique needs and communicating with them can be challenging. As a group, young female adults use more ECP than other groups do. Community pharmacists have regular, direct contact with young adults especially in the topic of ECP, so community pharmacists can benefit from developing specialised communication skills. Though communication is not an exact science and that strategies differ according to patient needs and staff dynamics; however, a communication material can be a useful guide for community pharmacists when dealing with young female adults on ECP use. Based on the overall literature, the key elements of the communication material should be tailored towards the practice and experience of community pharmacists, and explored in terms of layout, flow and content appropriateness. In summary, strengthening communication skills and learning to communicate effectively with young female adults is the goal for community pharmacists in ECP.

This study makes significant contribution to the health communication interventions which compliments to existing publications. It is likely that the supporting evidence will logically change the way of ECP information to be communicated within the Malaysian pharmacy context. Primarily, this study recognised the solid connection between the competency of pharmacists in communicating ECP information and the desired outcomes of ECP use. An effective ECP communication by pharmacists will encourage the correct use of ECP in preventing unplanned pregnancy. The theoretical contribution of this study provides an understanding to the need of a guided communication process for pharmacists. This will ensure the ECP information provided is effective and consistent across pharmacists. At the same time, the guided communication process with printed materials is able to guide through cultural and religious challenges in communicating ECP. This study contextually contributes to the development of printed materials in ECP catering situation in Malaysia. Effective implementation of printed materials allows the potential benefits of connecting pharmacists and young female adults in ECP information transition. Therefore much likely an initiative will be adopted and ECP printed materials will be used as the practical tool in a larger scale within pharmacy network in the country.

\section{Implication and Recommendations}

The impact of Health Communication Models inclusive of threat-and-efficacy and media selection in ECP information communication process could be used by pharmacists in developing a professional counselling service to educate young female adults on top of fulfilling the ECP product demand. More can be explored on various communication channels of disseminate ECP information to increase the rate of use and proper usage of ECP. Furthermore, ECP communication materials not only guided the 
INTERNATIONAL JOURNAL OF ACADEMIC RESEARCH IN BUSINESS AND SOCIAL SCIENCES Vol. 10, No. 10, 2020, E-ISSN: 2222-6990 @ 2020 HRMARS

pharmacists but also to enable a more efficient ECP counselling process especially during peak hours of the business. From this study, policy makers could investigate existing communication channels and yet explore on advanced and inventive ECP information distribution channels to be implemented across all healthcare settings to enhance precise use of ECP across women in child-bearing age with only aim to knock down the impact of unplanned pregnancy rate in the country.

\section{References}

Alagrisamy, R., \& Arokiasamy, L. (2019). A Study on Young Female Adults' Intention and Adoption of Emergency Contraceptive Pill in Rural Malaysia. Global Business \& Management Research, 11(1), 505-515. http://search.proquest.com/docview/2236131896/

Batur, P., Kransdorf, L. N., \& Casey, P. M. (2016). Emergency Contraception. Mayo Clinic Proceedings, 91(6), 802-807. https://doi.org/10/1016/j.mayocp.2016.02.018

Bearak, J., Popinchalk, A., Ganatra, B., Moller, A. B., Tunçalp, O., Beavin, C., Kwok, L. \& Alkema, L. (2020). Unintended pregnancy and abortion by income, region, and the legal status of abortion: estimates from a comprehensive model for 1990-2019. The Lancet Global Health, 8(9), e1152-e1161. https://doi.org/10.1016/S2214-109X(20)30315-6

Bernhardt, J. M., Mays, D., Eroğlu, D., \& Daniel, K. L. (2009). New communication channels: Changing the nature of customer engagement. Social Marketing Quarterly, 15(1_suppl), 7-15. https://doi.org/10.1080/15245000902960924

Beyene, G. A. (2019). Prevalence of unintended pregnancy and associated factors among pregnant mothers in Jimma town, southwest Ethiopia: a cross sectional study. Contraception and Reproductive Medicine, 4(1), 8. https://doi.org/10.1186/s40834-019-0090-4

Bitzer, J., Abalos, V., Apter, D., Martin, R., \& Black, A. (2016). Targeting factors for change: contraceptive counselling and care of female adolescents. The European Journal of Contraception \& Reproductive Health Care, 21(6), 417-430. https://doi.org/10.1080/13625187.2016.1237629

Both, R., \& Samuel, F. (2014). Keeping silent about emergency contraceptives in Addis Ababa: a qualitative study among young people, service providers, and key stakeholders. BMC Women's Health, 14(1), 134. https://doi.org/10.1186/s12905-014-0134-5

Boyd, C., \& Dare, J. (2014). Communication skills for nurses. Chichester, England: Wiley Blackwell

Brooks, L. A., Manias, E., \& Bloomer, M. J. (2019). Culturally sensitive communication in healthcare: A concept analysis. Collegian (Royal College of Nursing, Australia), 26(3), 383-391. https://doi.org/10.1016/j.colegn.2018.09.007

Centers for Disease Control and Prevention. (2019, September 12). Unintended pregnancy. https://www.cdc.gov/reproductivehealth/contraception/unintendedpregnancy/index.htm

Epstein, R. M., Fiscella, K., Lesser, C. S., \& Stange, K. C. (2010). Why the nation needs a policy push on patient-centered health care. Health Affairs, 29(8), 1489-1495. https://doi.org/10.1377/hlthaff.2009.0888

Farris, K., Aquilino, M. L., Kimbel, J., Batra, P., \& Marshall, V. (2012). Using community pharmacies to reduce barriers to contraceptive use.

https://www.researchgate.net/publication/266825451_Using_community_pharmacies_to_r educe_barriers_to_contraceptive_use 
INTERNATIONAL JOURNAL OF ACADEMIC RESEARCH IN BUSINESS AND SOCIAL SCIENCES Vol. 10, No. 10, 2020, E-ISSN: 2222-6990 @ 2020 HRMARS

Fatimah, S., Razif, D., Hafizah, M. N., \& Aw, S. M. (2019). Knowldege, Awareness and Perception of Contraception among Students in a Public University. KnE Life Sciences, 4(13), 34-43. https://doi.org/10.18502/kls.v4i13.5223

Gajanan, M. (2015). Teenage use of over-the-counter morning-after pill doubles in a decade. The Guardian (London, England), Society News.

https://www.theguardian.com/society/2015/jul/25/teenage-morning-after-pill-over-thecounter-doubles-decade

Garrett, K. P., Widman, L., Francis, D. B., \& Noar, S. M. (2016). Emergency contraception: Sources of information and perceptions of access among young adults. Women \& Health, 56(6), 668-679. https://doi.org/10.1080/03630242.2015.1118727

Gonsalves, L., \& Hindin, M. J. (2017). Pharmacy provision of sexual and reproductive health commodities to young people: a systematic literature review and synthesis of the evidence. Contraception (Stoneham), 95(4), 339-363.

https://doi.org/10.1016/j.contraception.2016.12.002

Kapheim, G. M., Ramsay, J., Schwindt, T., Hunt, B. R., \& Margellos-Anast, H. (2015). Utilizing the Community Health Worker Model to communicate strategies for asthma self-management and self-advocacy among public housing residents. Journal of Communication in Healthcare, 8(2), 95-105. https://doi.org/10.1179/1753807615Y.0000000011

Hardavella, G., Aamli-Gaagnat, A., Frille, A., Saad, N., Niculescu, A., \& Powell, P. (2017). Top tips to deal with challenging situations: doctor-patient interactions. Breathe (Sheffield, England), 13(2), 129-135. https://doi.org/10.1183/20734735.006616

Härgestam, M., Hultin, M., Brulin, C., \& Jacobsson, M. (2016). Trauma team leaders' non-verbal communication: video registration during trauma team training. Scandinavian Journal of Trauma, Resuscitation and Emergency Medicine, 24(1), 37. https://doi.org/10.1186/s13049016-0230-7

Hattingh, H. L., Emmerton, L., Ng Cheong Tin, P., \& Green, C. (2016). Utilization of community pharmacy space to enhance privacy: a qualitative study. Health Expectations, 19(5), 10981110. https://doi.org/10.1111/hex.12401

Henning, M., Goto, A., Chi, C., \& Rudd, R. E. (2015). Community health workers as critical building blocks to strengthen health systems: a two-case study of innovative CHWs in Zambia and Japan. Journal of Communication in Healthcare, 8(3), 241-249. https://doi.org/10.1080/17538068.2015.1107309

Hersh, L., Salzman, B., \& Snyderman, D. (2015). Health literacy in primary care practice. American Family Physician, 92(2), 118-124. https://www.aafp.org/afp/2015/0715/p118.html

Higgins, T., Larson, E., \& Schnall, R. (2017). Unraveling the meaning of patient engagement: a concept analysis. Patient Education and Counseling, 100(1), 30-36.

https://doi.org/10.1016/j.pec.2016.09.002

Karanesheva, T. (2015). Choosing the communication channel - a factor for effective health communication. Bulgarian Journal of Public Health, 7(3), 35-47. https://www.cabdirect.org/cabdirect/abstract/20153411880

Kerr, A., Strawbridge, J., Kelleher, C., Mertens, F., Pype, P., Deveugele, M., \& Pawlikowska, T. (2017). How can pharmacists develop patient-pharmacist communication skills? A realist review protocol. Systematic Reviews, 6(1), 14. https://doi.org/10.1186/s13643-016-0396-0 
INTERNATIONAL JOURNAL OF ACADEMIC RESEARCH IN BUSINESS AND SOCIAL SCIENCES

Vol. 10, No. 10, 2020, E-ISSN: 2222-6990 @ 2020 HRMARS

Korhan, O., \& Ersoy, M. (2016). Usability and functionality factors of the social network site application users from the perspective of uses and gratification theory. J Quality \& Quantity, 50(4), 1799-1816. https://doi.org/10.1007/s11135-015-0236-7

Liambila, W., Obare, F., \& Keesbury, J. (2010). Can private pharmacy providers offer comprehensive reproductive health services to users of emergency contraceptives? Evidence from Nairobi, Kenya. Patient Education and Counseling, 81(3), 368-373.

https://doi.org/10.1016/j.pec.2010.09.001

Lunsford, N. B., Sapsis, K. F., Smither, B., Reynolds, J., Wilburn, B., \& Fairley, T. (2018). Young women's perceptions regarding communication with healthcare providers about breast cancer, risk, and prevention. Journal of Women's Health, 27(2), 162-170.

https://doi.org/10.1089/jwh.2016.6140

Mayer, G. G., \& Villaire, M. (2007). Health literacy in primary care: A clinician's guide. New York, NY: Springer

McAree, D. P., \& Scott, E. M. (2004). Advice provision for women: Community pharmacists' attitudes and skills. International Journal of Pharmacy Practice, 12(1), 37-42. https://doi.org/10.1211/0022357023097

McKay, R., \& Gilbert, L. (2014). Use of IUDs for emergency contraception: current perspectives. Open Access Journal of Contraception, 5, 53-63. https://doi.org/10.2147/OAJC.S56399

Michie, L., \& Cameron, S. T. (2020). Emergency contraception and impact on abortion rates. Best Practice \& Research Clinical Obstetrics \& Gynaecology, 63, 111-119. https://doi.org/10.1016/j.bpobgyn.2019.06.008

Milosavljevic, J., Krajnovic, D., \& Bogavac-Stanojevic, N. (2016). Predictors of pharmacists' provision of emergency contraceptive pills. Health Care for Women International, 37(10), 1170-1181. https://doi.org/10.1080/07399332.2016.1215464

Najimudeen, M., \& Sachchithanantham, K. (2014). An insight into low contraceptive prevalence in Malaysia and its probable consequences. International Journal of Reproduction, Contraception, Obstetrics and Gynecology, 3(3), 493-496. https://doi.org/10.5455/23201770.ijrcog20140943

Pagano, M. P. (2009). Interactive case studies in health communication. https://books.google.com.my/books?hl=en\&|r=\&id=oYfJg6341dIC\&oi=fnd\&pg=PP1\&dq=Pag ano,+M.+P.+(2009).+Interactive+case+studies+in+health+communication.+Jones+\%26+Bartl ett+Publishers.\&ots=4MiuufLmza\&sig=WOaKYGQ2EMiZ-

OBvFHxXntLduj8\&redir_esc $=\mathrm{y} \# \mathrm{v}=$ onepage \&q\&f=false

Park, C. D. (2017). Nonverbal Communication: Insights, Importance in Healthcare Settings and Social Influences. Hauppauge, NY: Nova Science

Parvanta, C., \& Bass, S. (2018). Health Communication: Strategies and Skills for a New Era. Burlington, MA: Jones \& Bartlett Learning.

Peters, J., Desai, K., Ricci, D., Chen, D., Singh, M., \& Chewning, B. (2016). The power of the patient question: a secret shopper study. Patient Education and Counseling, 99(9), 1526-1533. https://doi.org/10.1016/j.pec.2016.07.012

Purnell, L. (2018). Cross Cultural Communication: Verbal and Non-Verbal Communication, Interpretation and Translation. In M., Douglas, D., Pacquiao, \& L., Purnell (Ed.). Global Applications of Culturally Competent Health Care: Guidelines for Practice (pp. 131-142). https://link.springer.com/chapter/10.1007/978-3-319-69332-3_14 
INTERNATIONAL JOURNAL OF ACADEMIC RESEARCH IN BUSINESS AND SOCIAL SCIENCES Vol. 10, No. 10, 2020, E-ISSN: 2222-6990 @ 2020 HRMARS

Purtilo, R. B., Haddad, A. M., \& Doherty, R. F. (2002). Health professional and patient interaction ( $8^{\text {th }}$ ed.). St. Louis, MO: Elsevier Saunders.

Ragland, D., Payakachat, N., \& Stafford, R. A. (2015). Emergency contraception counseling in a retail pharmacy setting: a pilot study. Journal of Pharmacy Practice, 28(3), 261-265. https://doi.org/10.1177/0897190013516507

Randrianasolo, B., Swezey, T., Van Damme, K., Khan, M. R., Ravelomanana, N., Lovaniaina Rabenja, N., Raharinivo, M., Bell, A. J., Jamieson, D., \& Behets, F. (2008). Barriers to the use of modern contraceptives and implications for woman-controlled prevention of sexually transmitted infections in Madagascar. Journal of Biosocial Science, 40(6), 879-893. https://doi.org/10.1017/S0021932007002672

Robbins, C. L., \& Ott, M. A. (2017). Contraception options and provision to adolescents. Minerva Pediatrica, 69(5), 403-414. https://doi.org/10.23736/S0026-4946.17.05026-5

Santibañez, S., Siegel, V., O'Sullivan, M., Lacson, R., \& Jorstad, C. (2015). Health communications and community mobilization during an Ebola response: partnerships with community and faithbased organizations. Public Health Reports (1974), 130(2), 128-133. https://doi.org/10.1177/003335491513000205

Saxena, P., Mishra, A., \& Nigam, A. (2016). Evaluation of pharmacists' services for dispensing emergency contraceptive pills in Delhi, India: a mystery shopper study. Indian Journal of Community Medicine: Official Publication of Indian Association of Preventive \& Social Medicine, 41(3), 198-202. https://doi.org/10.4103/0970-0218.183595

Strekalova, Y. A., \& Krieger, J. L. (2017). Beyond words: Amplification of cancer risk communication on social media. Journal of Health Communication, 22(10), 849-857. https://doi.org/10.1080/10810730.2017.1367336

Thomin, A., Keller, V., Darai, E., \& Chabbert-Buffet, N. (2014). Consequences of emergency contraceptives: the adverse effects. Expert Opinion on Drug Safety, 13(7), 893-902. https://doi.org/10.1517/14740338.2014.921678

Todd, N., \& Black, A. (2020). Contraception for Adolescents. Journal of Clinical Research in Pediatric Endocrinology, 12(Suppl 1), 28-40. https://doi.org/10.4274/jcrpe.galenos.2019.2019.S0003

Trussell, J., Raymond, E. G., \& Cleland, K. (2014). Emergency contraception: A last chance to prevent unintended pregnancy. Contemporary Readings in Law \& Social Justice, 6(2), 7-38. https://www.proquest.com/docview/1628965972? accountid=12528

United Nations International Children's Emergency Fund. (2015a). Commuity Care Centers, Community Dialogue and Engagement: Key Ingredients in Sierra Leone. https://www.unicef.org/cbsc/files/UNICEF_Community_Care_Centers(1).pdf

United Nations International Children's Emergency Fund. (2015b). Lofa County: Communities took the matter in their own brands.

https://www.unicef.org/cbsc/files/Communities_took_the_matter_in_their_own_handsLofa\%284\%29.pdf

United Nations. (2015). Trends in Contraceptive Use Worldwide 2015 (ST/ESA/SER.A/349). https://www.un.org/en/development/desa/population/publications/pdf/family/trendsCont raceptiveUse2015Report.pdf

Westley, E., \& Glasier, A. (2010). Emergency contraception: dispelling the myths and misperceptions. Bulletin of the World Health Organization, 88(4), 243-244.

https://doi.org/10.2471/BLT.10.077446 
INTERNATIONAL JOURNAL OF ACADEMIC RESEARCH IN BUSINESS AND SOCIAL SCIENCES

Vol. 10, No. 10, 2020, E-ISSN: 2222-6990 @ 2020 HRMARS

White, R. O., Eden, S., Wallston, K. A., Kripalani, S., Barto, S., Shintani, A., \& Rothman, R. L. (2015). Health communication, self-care, and treatment satisfaction among low-income diabetes patients in a public health setting. Patient Education and Counseling, 98(2), 144-149. https://doi.org/10.1016/j.pec.2014.10.019

Wong, L. P., Atefi, N., Abd Majid, H., \& Su, T. T. (2014). Prevalence of pregnancy experiences and contraceptive knowledge among single adults in a low socio-economic suburban community in Kuala Lumpur, Malaysia. BMC Public Health, 14(Suppl 3), S1-S1.

https://doi.org/10.1186/1471-2458-14-S3-S1

Yen, S., Parmar, D. D., Lin, E. L., \& Ammerman, S. (2015). Emergency contraception pill awareness and knowledge in uninsured adolescents: high rates of misconceptions concerning indications for use, side effects, and access. Journal of Pediatric and Adolescent Gynecology, 28(5), 337-342. https://doi.org/10.1016/j.jpag.2014.09.018

Yitayal, M., Berhane, Y., Worku, A., \& Kebede, Y. (2014). The community-based Health Extension Program significantly improved contraceptive utilization in West gojjam Zone, Ethiopia. Journal of Multidisciplinary Healthcare, 7, 201-208. https://doi.org/10.2147/JMDH.S62294

Yusof, M., Samad, A. A., Omar, M., \& Ahmad, N. A. (2018). Unplanned pregnancy and its associated factors. Global Journal of Health Science, 10(8), 132. https://doi.org/10.5539/gjhs.v10n8p132

Zain, N. M., Low, W. Y., \& Othman, S. (2015). Factors associated with pregnancy among unmarried women in Malaysia. Southeast Asian Journal of Tropical Medicine and Public Health, 46(3), 526-538. http://search.proquest.com/docview/1708581221/

Zonouzy, V. T., Niknami, S., Ghofranipour, F., \& Montazeri, A. (2019). An educational intervention based on the extended parallel process model to improve attitude, behavioral intention, and early breast cancer diagnosis: a randomized trial. International Journal of Women's Health, 11, 1-10. https://doi.org/10.2147/IJWH.S182146 